\title{
Småland och världen i några verk av Ann Margret Dahlqvist-Ljungberg
}

\section{Anna Salomonsson}

I skrivande stund har arton år passerat sedan Ann Margret DahlquistLjungberg (1915-2002) avled. I Ljungby, den stad där hon levde stora delar av sitt liv, känner stadsborna henne som illustratör och bildkonstnär men mitt intryck som inflyttad ljungybo, är att hennes lyrik, dramatik och prosa däremot har gått många förbi. För majoriteten i Ljungby är hon snarast känd som hustrun till ortens store konstnär, Sven Ljungberg (1915-2010). Denne var en färgstark profil som med sin frispråkighet och samhällskritiska röst blev ett välkänt namn i Ljungby för långt fler än bara stadens kulturintresserade. Mot bakgrund av att hon levde och verkade i makens hemstad föreligger en risk att Ann Margret Dahlquist-Ljungbergs mångsidiga konstnärskap har hamnat något i skymundan. En anledning till det kan vara att Ljungby som motiv inte tar plats i Ann Margrets skapande på ett lika explicit sätt som hos maken Sven, som har skildrat den småländska industristaden i otaliga färgstarka naivistiska målningar. Som Ingrid Nettervik har påpekat skulle Dahlquist-Ljungbergs finstämda naturskildringar lika gärna kunna ha inspirerats av det öländska landskapet som det småländska. I sin sommarstuga på Öland tillbringade paret Ljungberg nämligen långa perioder under somrarna (Nettervik 1998: 178).

Det småländska landskapet gör sig dock påmint på vissa håll i hennes texter, och ibland även andra referenser som för tankarna till Småland. I det följande kommer jag att undersöka hur kopplingar till Småland framträder i några av hennes verk utifrån två olika ingångar: för det första genom att visa hur två av Dahlquist-Ljungbergs småländska inspirationskällor - Elin Wägner och Carl von Linné - framträder i några av hennes texter, och för det andra genom att peka på motiv i några av hennes dikter. Mest tonvikt kommer att ligga på samlingen Goddag och adjö (1956) och prosadikten 'Djävulsdans småländsk" (1950). Inledningsvis är det dock lämpligt att ge en kort bakgrund till hennes liv och konstnärskap.

Ann Margret Dahlquist föddes 1915 i Ulricehamn, Västergötland, som andra dottern av tre. Som barn lärde hon sig tidigt att läsa och skriva och ägnade sig ofta åt musik och litteratur, intressen som delades av övriga $\mathrm{i}$ familjen (Millroth 2016: 9, 11). I nioårsåldern drabbades hon av öroninflammation, och efter en rad misslyckade operationer var dövheten ett faktum. Trots sitt handikapp började hon 1931 studera vid Tekniska skolan i Stockholm, sedermera Konstfack, och träffade där så småningom Sven Ljungberg. Till dennes hemstad Ljungby flyttade de efter studier och giftermål 1942, och bosatte sig i hans föräldrahem nära Lagaåns strand i 
centrala delen av staden. På samma tomt ligger idag Ljungbergmuséet Kronobergs läns bildkonstmuseum - och här finns en permanent utställning med många av hennes verk samlade

Fastän Ann Margret Dahlquist-Ljungberg befann sig, nationellt sett, i ett litterärt och idémässigt centrum under flera decennier ges hon inte mycket utrymme i senare litteraturhistorieskrivning. Som Jenny Björklund har visat $\mathrm{i}$ sin avhandling Hoppets lyrik (2004), framhölls Dahlquist-Ljungberg däremot av samtida kritiker som en lovande poet bland de så kallade 40-talisterna (Björklund 2004: 279). Till skillnad från generationskamraterna Ella Hillbäck och Rut Hillarp fanns hon representerad i Erik Lindegrens och Karl Vennbergs utgåva av 40-talslyrik från 1946, liksom i Bengt Holmqvists utgåva fem år senare (Björklund 2004: 240). Visserligen har hennes konstnärliga särart ibland uppmärksammats genom åren, bland annat ser Matts Rying henne som "en skald och konstnär, vars eld är av de största $\mathrm{i}$ landet" (Rying 1970) och Ragnar Matsson beskriver henne som "en brinnande ande i Småland" (Matsson 1975), men hennes författarskap har inte studerats nämnvärt. Med tanke på hennes mångsidiga produktion torde hennes texter ligga rätt i tiden, inte minst de delar som rör miljö- och klimatfrågor.

\section{Dahlquist- Ljungberg, Wägner och Linné}

Beträffande miljöengagemanget kan Ann Margret Dahlquist-Ljungberg, i likhet med förebilden Elin Wägner, räknas som något av en pionjär. Därutöver hade de båda ett samhällsintresse i stort, inte minst kretsade detta kring kvinnors rättigheter samt freds- och miljöfrågor. För DahlquistLjungberg tog det sig uttryck i litterära texter och bildkonstverk, och hon var dessutom aktiv i nationell debatt med skarpa inlägg i dagspressen. Hennes utställning Döden $i$ oljan fick stort genomslag 1976 och visades i både Göteborg och i Malmö (Millroth 2016: 194f.). Likaså uppmärksammades hennes bok Homo Atomicus (1980) på bred front. I den gestaltar hon med skrämmande illustrativa detaljer hur hon tänkte sig människors framtid om kärnkraftshotet blev verklighet.

Freds- miljö- och jämställdhetsfrågor var aktuella under denna tid och 1978 utkom en nyutgåva av Elin Wägners debattbok Väckarklocka från 1941. Redan 1958 hade Dahlquist-Ljungberg i sin essä "Till Väckarklocka" uttryckt besvikelse över att den fått oförtjänt negativ kritik och inte uppmärksammats tillräckligt. Om sin egen relation till boken skriver hon i essän från 1958:

I många år hade jag Elin Wägners Väckarklocka liggande på mitt sängbord, halvläst, halvuppskuren. Det finns böcker som vägrar lämna ut sig, eller som man inte är mogen för, och som man betraktar skeptiskt eller ljumt tills de plötsligt en dag, i rätta ögonblicket, öppnar sig och träffar som ett blixtnedslag. [...] När mötet sker med en så överraskande kraft blir det dess mer omstörtande."

(Dahlquist-Ljungberg 1989: 90) 
Boken kräver sin läsare och den förtjänar enligt Dahlquist-Ljungberg att tas på allvar. Att den var svårsmält, även för vissa professionella läsare och kritiker, befogade inte att den vid utgivningen 1941 fick ett sådant avmätt mottagande. Förutom att Dahlquist-Ljungberg beklagade att Wägners stilistiska styrkor inte betonas - "Hennes stil flödar av intressanta perspektivförskjutningar, plötsliga utblickar över slätter eller ner mot bråddjup" - reagerade hon på att Wägners syn på könsroller och modernitet inte hade diskuterats mer (Dahlquist-Ljungberg 1989: 96). I sin debattbok framhåller Wägner samhällsfaran $\mathrm{i}$ att den nya, moderna kvinnan har underordnat sig manssamhällets normer istället för att representera ett alternativt leverne präglat av ett ickehierarkiskt förhållningssätt och en närhet till naturen. Att Wägner inte hade fått ett erkännande av sina manliga kollegor var symptomatiskt, enligt Dahlquist-Ljungberg, med ett stort svek var också att kvinnor hade motarbetat henne (Dahlquist-Ljungberg 1995). Själv skriver Ann Margret Dahlquist-Ljungberg ett satiriskt skådespel som kommentar till detta fenomen, "Sången om Matriarkatta", publicerad i diktsamlingen Isöga (1978). Den utspelar sig i ett matriarkat som så småningom går under på grund av att de kvinnliga makthavarna blint tillämpar samma förtryckande medel som rått $\mathrm{i}$ manssamhället. Föremålet för dramats verkliga kritik är dessa patriarkala strukturer, även om de medlöpande kvinnopolitikerna också får sin beskärda del.

Att som kvinna kritisera mansnormen har historiskt haft sitt pris, och bland annat medfört att tvingas utstå förminskande kommentarer från dem som känt sig träffade. Elin Wägner fick erfara det, och så fick även Ann Margret Dahlquist-Ljungberg. Så sent som 1991 omnämns hon av Expressens Björn Nilsson i artikeln "Kärringilskans geografi" där Småland kan utmålas av Nilsson som ett av "den litterära kärringilskans område[n]". Exempel på dem han nedlåtande namnger är den "kavata" Astrid Lindgren och den "uppdrivet satiriska" Ann Margret Dahlquist-Ljungberg (Nilsson 1991).

År 1995, sjutton år efter "Sången om Matriarkatta" och efter nyutgåvan av Väckarklocka, frågar sig Dahlquist-Ljungberg varför Wägners debattbok inte publiceras på nytt "och tas upp till angelägen debatt - till avhandlingar och forskning? Tiden borde vara mogen - med perspektiv på vad som händer och alltjämt händer" (Dahlquist-Ljungberg, 1995). Idag, tjugofem år efter uttalandet, är frågan minst lika aktuell.

Om Wägner var en författarförebild för Ann Margret Dahlquist-Ljungberg beträffande 1900-talets angelägna samhällsfrågor, var 1700-talets Linné en förebild vad gäller blicken för naturens allra minsta, sinnrikaste detaljer. Med sin förmåga att så förfinat gestalta naturens finkalibriga komponenter och förmedla det meningsfulla i deras varje detalj, är det förståeligt att DahlquistLjungberg influerades av Smålands blomsterkung. Hon var väl inläst på Linné och delade dennes fascination för växter och deras unika karakteristika (Millroth 2016: 55, 58). I dikten "(sommarpredikan)" ur diktsamlingen 
Rapport om öar (1957) hyllar hon honom med, vad Nettervik skriver, en "naturens egen klockringning" (Nettervik 1998: 180):

\author{
Det dånar som från en liten landskyrka \\ vid sjön Möckeln, över hagar och löväng \\ över bisummig kryddgård, humleland \\ och doftande lönn framför Råshults trappsten \\ Synnerligast om sommaren, den ljuva \\ mitt i härligaste fröjd, högast $\mathrm{i}$ höjden \\ på det att vi icke må förhäva oss: \\ blir vi upplysta med insikt \\ huru allt går ikring \\ Huru vist är icke allt proportionerat \\ Vart och ett, stort som smått, har fått \\ sin kuse över sig
}

Den vackra naturskildringen är en hyllning, tillräcklig i sig själv, men att det landskap som skrivs fram är Linnés egen barndomstrakt ger skildringen en ytterligare meningsdimension. Klockorna som ringer intill sjön Möckelns strand i dikten är kyrkklockorna i Stenbrohult kyrka där Carl von Linnés far tjänstgjorde som präst och där sonen tillbringade mycket tid som barn. Några kilometer från Stenbrohult ligger i sin tur hemgården i Råshult dit klockornas klang i dikten fortplantar sig "över hagar och löväng/ över bisummig kryddgård, humleland/ och doftande lönn". Att ljudet från kyrkklockorna "dånar" blir vidare till en stark påminnelse om att människans plats i denna natur är, i likhet med allt annat levande, begränsad. Alla små delar är väl uttänkta, "vart och ett, stort som smått" har någon under sig såväl som över sig att förhålla sig till. I dikten betonas den litenhet som också är människans, inför det stora hela. "Vi" i bemärkelsen "vi människor" bör ödmjukt inse vår begränsade plats i helheten för att inte riskera att drabbas av högmod, och "förhäva oss". Men - där Linné inkluderar Gud i sin världsbild och ser människan som skapelsens krona som ödmjukt måste underordna sig Guds ordning, är det enligt Ann Margret Dahlquist-Ljungberg inför naturen som människan bör visa sin ödmjukhet. Hennes religionskritik finns dokumenterad i flera av hennes verk, där hon flera gånger återkommer till slutsatsen att Gud är maktlös (Millroth 2016: 92). Med denna ståndpunkt skiljer sig alltså hennes syn på relationen mellan människa och natur från Carl von Linnés kristet-religiöst präglade hållning.

Linné återfinns mer explicit $\mathrm{i}$ en annan av hennes dikter i samlingen Rapport om öar, den här gången i skepnad av en ängel med blicken riktad mot den jord han lämnade flera århundraden tidigare. Bekymrat betraktar Linné jorden som den nu ser ut och konstaterar att de stolta lindarna på hans gård i Råshult inte längre står kvar. Inte heller är hagar och ängar desamma vare sig i hans hemtrakter eller på annat håll. Härigenom, via diktjaget Linné, riktar Dahlquists-Ljungberg en kritik mot ohämmad modernisering och 
miljöförstöring. Han ser hur vattendrag har byggts ut, hur städer med plastfabriker och tunnelbanor vuxit fram där vackra landskap tidigare brett ut sig och hur vattendrag har byggts ut och sjöar förorenats. Moderniseringen har satt sina spår. Men i dikten låter hon inte Linné stå oemotsagd. Emmanuel Swedenborg svarar honom, till en början skälmskt:

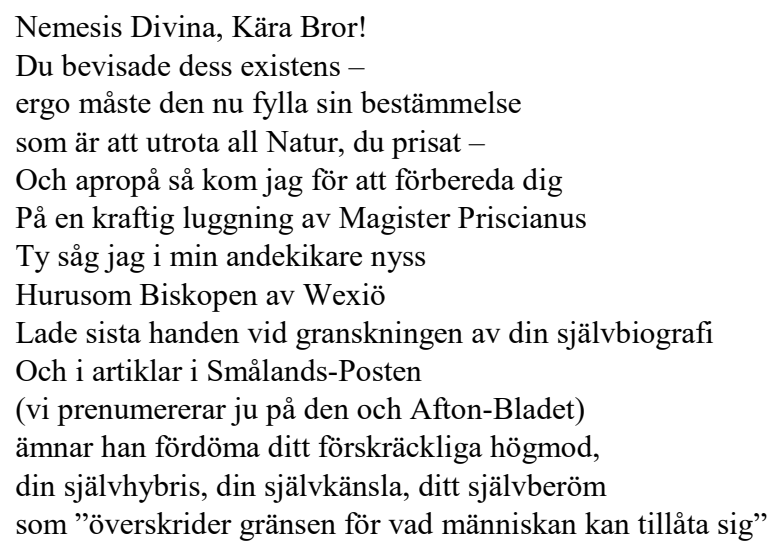

Efter diverse replikskiften låter Dahlquist-Ljungberg de båda änglarna Linné och Swedenborg försonas och istället smida gemensamma planer mot Biskopen av Wexiö. Författarens humoristiskt satiriska ådra är inte att ta miste på.

\section{Goddag och Adjö. Politisk satir om småstad och storstad}

Maktkritiska budskap riktade författaren också mot lokala politiker som saknade kunskap om estetiska och kulturhistoriska aspekter. Hon och maken Sven protesterade aktivt mot hur Ljungby i deras mening förfulades av denna ogenomtänkta stadsplanering. Ljungby förändrades från att vara en småstad med äldre bebyggelse till en stad som, likt många svenska småstäder under 1960-talet, ersatte gamla trähus med dussinhus gjorda i sten och betong. Denna rivningsiver var ett exempel på modernisering som enligt paret Ljungberg var förödande. Sven Ljungberg skrev fräna inlägg i lokaltidningen och tog målarpenseln till hjälp för att nå ut med sin kritik. Ann Margrets engagemang var också starkt men, som Thomas Millroth har påpekat, kanaliserades detta via ett perspektiv som även sträckte sig bortom det lokalpolitiska (Millroth 2016: 164).

Ett exempel på hur hennes kritiska udd riktar sig åt flera samtidiga håll visar hon redan 1956 i den lilla boken Goddag och Adjö. Den innehåller korta verser och illustrationer om hur livet kan te sig i en småstad av Ljungbys storlek. Under pseudonymen Lotten Lovell-Svensson antar hon ett satiriskt stilgrepp i skildringen av staden Kråsnåla och några av dess invånare. Till skillnad från i Rapport om öar där hon lät vetenskapsmännen Linné och Swedenborg mötas, är det nu vardagens samtidsmänniskor som skildras. I 
boken rör sig författaren mellan olika jag-positioner genom att använda sig av fiktiva författarjag, dels en fiktiv författare av förordet, Jeremias Myrstig, dels en till själva diktsamlingen: Lovell-Svensson, en hemmafru med författarambitioner boende $i$ en svensk småstad. Vissa paralleller kan nog dras till Dahlquist-Ljungbergs eget liv i Ljungby (Millroth 2016: 156), och det fiktiva "företalet" av Myrstig är ett underhållande stycke text som innehåller flera ironiska tvister. Det inleds på följande sätt:

Lotten Lovell-Svensson föddes, levde och dog i Kråsnåla, den lilla staden inne i mörkret av det mörkaste Småland. Hennes liv förflöt lugnt och borgerligt endast med en och annan krusning av de vanliga familjebekymren, i likhet med den staden genomporlande Kråsnålaån. Få av omgivningen anade väl att en konstnärssjäl andades under husmorsförklädet, att det var en skarpsynt och granskande iakttagare som rörde sig på kafferep och middagsbjudningar eller som i ett hemligt minne samlade anteckningar om den lilla stadens liv och leverne - och anteckningar såväl i bild som ord. (Dahlquist-Ljungberg 1956: 3)

Den fiktiva biografiska beskrivningen av Lovell-Svensson ger en extra ironisk krydda till läsningen av de dikter som sedan följer. Att Ljungby utgör förlaga till Kråsnåla, är inte en långsökt gissning - bland annat beskrivs den porlande Kråsnålaån passera genom staden, vilken har sin motsvarighet $\mathrm{i}$ verklighetens Lagaån, som flyter genom Ljungby. Som nämnts är kritiken mot Ljungbys lokalpolitik något som paret Ljungberg uttryckte också vid sidan av sitt konstutövande. Samtidigt är det inte endast Ljungby som åsyftas, utan alla småstäder och orter, där småborgerliga ideal präglar stadsandan. Hon höjer blicken och beskriver det fyrkantiga, byråkratiska styret som kan finnas i en svensk småstadskommun, var som helst i Sverige.

I förordet hänvisas vidare till en intervju där Lovell-Svensson beskriver "hur hon diktar mellan hushållsbestyren - 'en köttbulle här, en vers där'"(s. 7). Mot bakgrund av tiden för bokens utgivning och 1950-talets husmorsideal, skulle beskrivningen av Lovell-Svenssons liv och verk kunna ses som en socialsatirisk kommentar till dåtidens borgerliga samhällsnormer och småstadsbornas tämligen ytliga förehavanden. Att hon bär namnet "Svensson" behöver inte vara en slump, utan kan rimligen hänvisa till det allmängiltiga, typiskt svenska som det efternamnet ofta representerar.

Men boken rymmer även en sprittande berättarglädje som förmedlar något mer än kritik. Goddag och Adjö två första kapitel, "Ur Fridas filosofi" och "Ur Fridas älskog" för lätt tankarna till Birger Sjöbergs Fridas bok (1922), där flera av visorna med mild humor tecknar bilder ur livet i en småstad, inte olik Sjöbergs hemstad Vänersborg. I Goddag och Adjö delger diktjaget Frida, som enligt Jeremias Myrstig är Lovell-Svenssons alter ego, sina skarpa betraktelser också hon med småstadslivet som fond. Den lätta ironin som genomsyrar de rytmiska små anekdoterna, bidrar till att göra dem lättillgängliga för läsaren. Redan i det första kapitlets lilla dikt "Cause celebre" finns spår av det småländska i den omisskännliga dialekten. Här möts 
det lilla och det stora då flickan Frida med viss smärta får erfara "den stora världen":

Min första hågkomst tycks mig rätt bisarr:

En herre brände mig med sin cigarr.

Världskonfronterad på en marknadsfest

Blev jag ett offer för en slarvig gest.

Raketerna som nyss mot rymden ränt

Jag följde med mitt öga uppåtvänt.

En helt och hållet oavsiktlig glöd

Var det som brände då min näsa röd.

Min fader höll mig ömt tryckt till sitt bröst.

Än hör jag genom tidens flykt hans röst:

"Min stackars lella tös som bränt sej så

Att hennes skinn på näsa har gått å"

Det högtravande i titeln "Cause celebre", gestaltat av de högtflygande fyrverkerierna och den cigarrökande mannen, kontrasteras effektfullt mot den småländska flickan och hennes far, särskilt den senare som talar med en jordnära, platsförankrad småländska.

Det tredje kapitlet, "Någras lilla stad", innehåller ett antal korta skildringar av vardagliga händelser som alla tar plats i den kommunala offentligheten. Här tecknas såväl korrupta lokalpolitiker som en rektorska Plommonblom och en doktor Njuman, alla med starkt karikatyrartade drag. Samtliga verser parodierar makthavarnas roll som demokratins representanter, med rubriker som "Hemligt sammanträde ang: norra infartsvägen" och "Ang: kulturlivets uppryck- och utvidgning". Den kritiska udden riktas främst mot de styrande och privilegierade och inte mot småstadsborna i allmänhet, även om "fisförnäm småstadsmentalitet" gisslas här och var (Millroth 2016: 158). Bland annat märks det under rubriken "Ang: Lokala konstföreningens månadssamkväm" där det skildras hur Kråsnålaborna okritiskt beundrar en "konstprofet" som besöker dem från huvudstaden. Avsnittet kan i första hand dock utläsas som en satirisk uppgörelse med självgoda konstkännare från Stockholm som till syvende och sist inte visar sig vara förmer än någon annan:

Från Hufvudstaden nedrest Konstprofet

föreläser främst om Art Konkret.

Med ljusfilm ger han teserna belägg.

Dock är det intressantaste hans skägg

[...]

Belöningen: supé för menigheten

Då blir man du och bror med konstprofeten. 
Medan en sandwich naggas uti gapen

talar man lärt om Konst med sakkunskapen.

[...]

Med fröken Pullan sen han raskt försvinner

innan de andra till sin nattgrogg hinner.

O kvällar lyftade av Konstens ljus!

O lycka Liljefors ha i sitt hus!

Nästkommande kapitel, "Porträtt", beskrivs i Myrstigs förord som en huvudstadspendang till "Någras lilla stad". Så betraktat blir porträtten till satiriska kommentarer med udden riktad även här mot vissa ur storstadseliten, observerade med Lovell-Svenssons småländska småstadsblick. Den sociala satiren inskärps, menar Millroth, kanske på grund av att betraktaren av denna värld är en kvinna ur ett perifert perspektiv (Millroth 2016: 156). Kapitlets verser bär alla rubriken "Rosenbad" följt av ett klockslag. De utgörs av anteckningar, noterade av Lovell-Svensson, som jag tolkar det, sittande på avstånd med block och penna på Restaurang Rosenbad från kl. 19.50 fram till midnatt. Avsnittets sista dikt "Rosenbad kl. 00.00" lyder som följer:

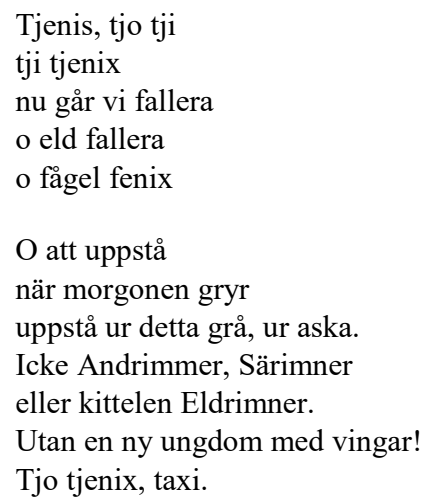

En och annan drink tycks vid det laget ha slunkit ned hos dem som skildras, men inte utan att de hasplar ur sig lärda referenser från nordisk mytologi som speglar deras självbild som samhällets upphöjda. I och med diktens sista ord - det vardagsnära "taxi" - placeras desamma på marken igen, tack vare Lovell-Svenssons satiriska penna. Som Tomas Millroth skriver parodierar de här porträtten "dåtida modern poesi och dess upphovsmän, när hela författarmenageriet möts på restaurang Rosenbad" (Millroth 2016: 158). Den kritiken förmedlas dessutom, kan jag tycka, genom författarens val av berättarform, i det här kapitlet liksom i boken som helhet. Det flertalet nivåer av alias och former av subjektsupplösningar i Goddag och Adjö som helhet, samt all blandning av högt och lågt $\mathrm{i}$ stil och innehåll, är tecken på det. Millroth pekar också på författarens blinkning till Alice i Underlandet, då hon låter Cheshire-katten vara vinjett på bokens baksida (Millroth 2016: 159). 
Och visst kan man se det så. Med boken Goddag Adjö parodierar DahlquistLjungberg, lekfullt och bitande, maktens institutioner på såväl lokal som nationell nivå - i något som kan likna en carrollsk absurdistisk tradition.

\section{Djävulsdans småländsk. Om modernisering och makten över liv och död}

En absurdistisk ton märks även i den tidiga prosadikten "Djävulsdans småländsk" som ingår i samlingen Djävulsdans från 1947. Diktjaget är en småländsk urmakare "som på grund av svår nervsjukdom åtnjuter Invalidpension av Staten och Allmän Aktning av byn" (s. 94) och som i diktens efterord beskrivs bli hittad död, stående $\mathrm{i}$ fodralet till sin Moraklocka, som tidigare kallat "djävulskatedralens trånga kor" (s. 113). Han ser sig som Djävulens representant i egenskap av urmakare och eftersträvar att kontrollera tiden - och därmed livet och döden. Urmakaren har skapat en helvetesmaskin i form av en klocka som han anser vara ett effektivare massmordsvapen än atombomben (s. 96f). Oåterkalleligt dränerar den människan på hennes livstid. Han är väl medveten om "tidens jäkt, maskinmänniskan och kulturen, vinsten av några minuter contra förlusten av en själ' (s. 105). Att han i slutet går under på grund av sitt speciella förhållande till tid kan förstås som en kritik mot den moderna människans fixering vid effektivitet och mätandet av tid men också mot det meningslösa krig som avslutats endast några år innan dikten skrevs. "Jag vill dö upprättstående. Som ett klocklod" (s. 113) skriver urmakaren. Med vetskap om närheten i tid mellan diktens tillkomst och andra världskriget samt att urmakaren bär det tyskklingande namnet Wasser, kan hans upprättstående död associeras till bilden av en tysk militär i givakt.

Död och ondska förekommer alltså inte bara i krigssammanhang utanför landets gränser utan också i Sverige och i Småland. Genom angivelsen av berättelsens geografiska spelplats betonas samröret mellan den lilla världen och den stora. Som jag ser det kan adjektivet "småländsk" i titeln tillföra den sammanlänkande betydelsen - den att även den till synes perifera platsen och dess människor står $\mathrm{i}$ förbindelse med övriga världen och att ondska och galenskap så till vida kan finnas också i skepnaden av en urmakare i Småland.

I övrigt framträder inte kopplingen i dikten mellan Småland och världen särskilt tydligt i dikten, men den glimtar fram exempelvis i urmakarens beskrivning av sina nattliga våndor av vaka:

Ny stjärna tänd. Motvillig spegling, spegling även sen ögat bortvänt. Men tänker på alla de andra som speglas - över Tanganyika, Jang-Tse-Kiang, i Manyuls-sur- Mer, Pskov och Anticoli Corrado.

För inte samma stjärna väl som speglas där och här. Här - där, i grumliga ögon bakom brädupplag, i tältöppningar och perspektivfönster. Den sitter ju på grantoppsbarret fast, kan flyga för min blinkning. Åttauddade havets stjärna skådad från förstutrappan till en stuga mitt i Småland, det stora smålandshavet. (s. 93) 
De existentiella grubblerierna kretsar kring hans egen plats i världen, och rymmer också ett sanningssökande som kopplas samman med tid: "Ibland är jag sanningen nära, bara tiden vore lite längre bredare högre djupare skulle jag nå den, men just som jag är i själva gripandets sekund, begripandets, flyger tiden undan med nästa sekund som en gyllenhuvad grip. Jag hinner ju inte, hinner hinner inte" (s.99). Han tycks vilja förstå och kontrollera själva evigheten: "Om det bara fanns det uret. Uppleva hela tiden i ett enda ögonblick, framtiden och forntiden tillsammans på en enda visartavlas eviga nu" (s. 91).

Urmakarens tankar om tidens relativitet framkommer även i hans arbetsvardag då han konstaterar att två av hans klockor har hamnat i bråk. Det är "den stora Moraklockan och gamla amerikanska vägguret" som "förnekar varandras verklighet och påstår att det är helt olika tider de mäter ut" (s. 94). Mest synd tycker han emellertid om sig själv som står i korselden mellan dessa tider och platser som strider om tolkningsföreträde, dessa " omätbara pendlingar fram och åter, upp och ner - verklighetens varseblivningar [...]. Det enda som alltid är oföränderligt och detsamma är Djävulens dans när han i oräkneliga upplagor återkastad av rummets facettslipade glaskropp och mina irrande ögon hoppar sina osynliga steg" (s. 95). Sammantaget kan den galne urmakaren i dikten ses som ett slags pendang till det välkända motivet om den galna vetenskapsmannen som leker Gud. Men - här är det alltså en småländsk urmakare som spelar Djävulen.

"Djävulsdansen" som urmakaren refererar till är något alla människor måste underordna sig, oavsett tid och rum. I dikten är dansen likställd med tiden - och i förlängningen döden. Men naturen som motiv finns med också här. I en monolog beskriver urmakaren hur lövgrodor och humlor i klöverblom, liksom varje människa, lever i falsk trygghet lyckligt ovetande om omkringvarande hot:

Egentligen - finns någonstans ett gömme där man är trygg för sig själv? Där långsamt alla fordringar, all identitet rinner av en medan daggen faller -

Lövgrodorna hoppar i gräset på väg till källan, humlorna har redan klängt sig fast under klöverblommorna i sin oändliga tillit att ingen klumpig träsko - (s. 93)

Den klumpiga småländska träskon kan innebära slutet för humlan. På motsvarande sätt kan, via ett perspektivskifte, människor i Småland och annorstädes krossas av militärkängors stöveltramp. Betraktat med en sådan dubbelexponering synliggörs i dikten åter igen spår av det nyss avslutade världskriget.

\section{Den småländska naturen och det allmänmänskliga}

De poetiska inslagens dubbelhet i "Djävulsdans småländsk" överensstämmer med hur Dahlquist-Ljungberg även i andra texter sammanför det lilla med det stora, inte minst $\mathrm{i}$ hennes målande av naturmotiv - gestaltningen av djurs och växters samspel och kretslopp visar på tidens närvaro och oåterkalleliga gång. 
Tiden och naturen som motiv går oftast hand $\mathrm{i}$ hand. Ett exempel då detta tränger fram mellan raderna, är i dikten "De utskurna hjärtana" ur diktsamlingen Brudbuketten (1954):

Skog öppnar sig och vattnet öppnar sig - först nu när spänningen släppt kunna ta emot landskapet och känna ömhet välla upp inom sig för detta övergivna ställe där spindlarna vävt fångstnät från träd till träd, från buske till buske, över ljungtuvor och mellan epilobiumspirornas torra dunfladdrande prasselsnår och kransborrens knastrande nålvassa bladförsteningar.

Ett övergivet torp målas fram, stående i gläntan i tät småländsk skog. Skogslandskapet bryts plötsligt upp av en liten sjö. Bilder av hur ljungtuvor och vävda spindelnät mellan träd och buskar levandegör det ödsliga smålandskapet och väcker nostalgi och sympati hos diktjaget. Nutid möter dåtid. Också Nettervik har uppmärksammat de småländska inslagen i Brudbuketten och framhåller författarens imponerande detaljrikedom och språkliga skärpa i beskrivningarna av "den åldrade stugan i skogen" och nyckelpigornas ryggsköldar som öppnar sig och lyfter" (Nettervik 1998: 179).

Dahlquist- Ljungbergs sammanför det specifika med det allmänna i många av sina dikter. I "Hemkomst" ur antologin De döda barnen (1944) omvandlas även hennes personliga erfarenheter av sorg till allmängods. Där skriver hon fram trädgården till det nya hemmet i Ljungby som en efterlängtad plats för vila och återhämtning efter att ha tillbringat åtta veckor på sjukhus i sviterna av ett olyckligt missfall. Tomas Millroth kallar "Hemkomst" för något av en "tröstedikt, en vår- och sommardikt" (Millroth 2016: 73):

En gammal trädgård doftar av syren

och hagtorn blommar där och anemon.

Högst upp i almen stararna har bon

Och floden flyter nedom björkallén.

Så enkelt kärleksfullt det är.

I gräset dalar äppelträdens snö

Hur kom jag hit - och skall jag inte dö?

Jag känner något sällsamt spira här.

Ett sjukt och sargat hjärta finner ro 
och tillit bräddar själen tusenfalt

- O Gud att detta händer överallt

var stund, för alla vilsna, vill jag tro

Ann Margret Dahlquist-Ljungberg skildrar med skarpögd iakttagelseförmåga naturens minsta växter och djurliv, och med detta gestaltar hon även det finkänsligt mänskliga, och ibland onämnbara. Som här - ett känslotillstånd av samtidig sorg och förtröstan, som, i någon mån, rör oss alla.

Genom att i sitt konstnärskap dessutom blanda genrer och stilgrepp, realistiska inslag med mytologiska och absurdistiska samt kombinera det textuella berättandet med det visuella, visar hon upp ett djup och en utomordentlig bredd. Tack vare denna mångsidighet har hon verksamma medel att $\mathrm{i}$ ord och bild kombinera sina konstnärligt utforskande ambitioner med sitt samhällspolitiska engagemang. Dessa två stråk kan urskiljas även i hennes gestaltningar av det småländska. Härvidlag kan hennes småländska föregångare och inspirationskällor få representera de båda drivkrafterna. Dels kännetecknas hennes texter och bilder av hur hon, likt Linné, med stor detaljrikedom frammejslar naturens små underverk, med blick för det vackra i det lilla och anspråkslösa, exempelvis i en småländsk trädgård utmed Lagaån. Dels präglas hennes konstnärskap av en samhälls- och modernitetskritik i Elin Wägners anda - en kritik riktad mot manssamhället och miljöförstöring såväl som mot inskränkt gruppmentalitet, må det så vara i Ljungby, i Stockholm eller i världen i stort. Dahlquist-Ljungbergs perspektiv rymmer på så vis den dubbelhet som ofta kännetecknar ett stort konstnärskap - det komplexa förenandet av det lilla och det stora, det specifika och det generella.

\section{Referenser}

Björklund, Jenny (2004). Hoppets lyrik. Tre diktare och en ny bild av fyrtiotalismen. Ella Hillbäck, Rut Hillarp och Ann Margret DahlquistLjungberg. Stockholm Stehag: Brutus Östlings förlag.

Carlsson Stig (1951). "Döden och dansen. Motiv i Ann Margret DahlquistLjungbergs lyrik och grafik" i Perspektiv, nr 7. s. 413-420.

Dahlquist-Ljungberg, Ann Margret (1950), Djävulsdans. Stockholm: Bonniers. Dahlquist-Ljungberg, Ann Margret (1955). Brudbuketten. Stockholm: Bonniers.

Dahlquist-Ljungberg, Ann Margret (1956). Goddag och adjö. Stockholm: Bonniers.

Dahlquist-Ljungberg, Ann Margret (1957). Rapport om öar. Stockholm: Bonniers.

Dahlquist-Ljungberg, Ann Margret (1978). Isöga. Stockholm: Norstedts

Dahlquist-Ljungberg, Ann Margret (1980). Homo Atomicus. Stockholm: Bonniers. 
Dahlquist-Ljungberg, Ann Margret (1989). "Väckarklockan ringer". Kvinnor $i$ Småland I. Smålands Författarsällskaps skriftserie. Kristianstad: Halls förlag. s. 90-99.

Dahlquist-Ljungberg, Ann Margret (1995). Förord till Elin Wägner-sällskapets skriftserie, Växjö: Elin Wägner-sällskapet.

Ljungberg, Sven (2001). ”Ann Margret Dahlquist-Ljungberg - de stora mästarnas krets”, i Kvinnor i Småland II. Smålands Författarsällskaps skriftserie. Gamleby: PM Bokförlag. s. 170-181.

Matsson, Ragnar (1970). "Vattenspindeln, skuggan och Pasiphae - tre steg till Ann Margret Dahlquist-Ljungberg", Böckernas värld, nr7.

Millroth, Tomas (2016). Ann Margret Dahlquist Ljungberg. Rimforsa: Almlöfs.

Nettervik, Ingrid (1998). "Ann Margret Dahlquist-Ljungberg - brinnande ande i Småland”. Författare i Småland. Stockholm: Carlssons Bokförlag, s.178181.

Nilsson, Björn (1991). "Kärringilskans geografi” i Expressen, 1991-08-31.

Rying, Matts (1975). "Ljungbergs i Ljungby", i Resa och rast. Stockholm: Rabén \& Sjögren. 